\title{
SOBRE A RELEVÂNCIA FILOSÓFICA DO ARGUMENTO DO MILAGRE
}

\author{
Edna Alves de Souza ${ }^{1}$
}

\begin{abstract}
Resumo: Neste artigo, argumentamos a favor de uma versão sofisticada do realismo científico, tendo como eixo norteador a análise do desempenho do que consideramos ser o seu elemento de defesa estratégico: o "argumento do milagre". O realismo científico é a perspectiva comprometida com as nossas melhores teorias científicas, isto é, com a existência de entidades, processos, relaçôes etc., observáveis ou inobserváveis, indispensáveis para explicar o seu sucesso empírico, em particular, com aqueles componentes das teorias que são cruciais para se alcançar novas previsôes bem-sucedidas. $\mathrm{O}$ argumento do milagre é um tipo de abdução ou inferência da melhor explicação e se expressa na célebre formulação de Putnam (1975, p. 73): "O realismo científico é a única filosofia que não faz do sucesso da ciência um milagre." Analisamos e rebatemos duas importantes modalidades de argumentação antirrealista: a induçâo pessimista e a circularidade viciosa da inferência da melhor explicação. Acreditamos estar justificados quanto à defesa da intuição básica do realismo científico, com o apoio de uma versão fortalecida e articulada do argumento do milagre, mediante as qualificaçôes de novidade preditiva e fecundidade teórica: a ciência é bem-sucedida em explicar e prever fenômenos, inclusive novos, porque suas melhores teorias (maduras, não ad hoc, bem-sucedidas empírica e instrumentalmente, provedoras de previsóes novas, fecundas etc.) são (parcial ou aproximadamente) verdadeiras e as entidades inobserváveis postuladas por essas teorias realmente existem. Concluímos que o argumento do milagre continua sendo basilar e estratégico na defesa do realismo científico.
\end{abstract}

Palavras-chave: Realismo científico. Argumento do milagre. Antirrealismo. Novidade preditiva. Fecundidade teórica.

\section{INTRODUÇÁO}

São muitas as formulaçôes do realismo científico, constituindo um verdadeiro desafio apresentar uma caracterização geral dessa perspectiva filosófica que seja satisfatória, de modo a acomodar suas variaçóes e qualificaçôes diver-

\footnotetext{
1 Pesquisadora de Pós-Doutorado pelo Programa de Pós-Graduação em Filosofia da Universidade Estadual Paulista (Unesp), Marília, SP - Brasil. (D) https://orcid.org/0000-0002-5503-3753 E-mail: souzaednaalves@gmail.com

Bolsista PNPD-CAPES.
}

http://dx.doi.org/10.1590/0101-3173.2019.v42n4.04.p47 
sas. Considerando tal dificuldade, oferecemos neste artigo, preliminarmente, uma caracterização ampla do realismo científico, apoiada em um de seus aspectos distintivos, e, na sequência, preenchemos algumas de suas lacunas, ao adentrarmos na discussão entre realistas e antirrealistas científicos sobre a relevância do argumento do milagre para a defesa da perspectiva realista. Entendemos que o coração do realismo científico seja uma atitude epistêmica otimista frente aos resultados da investigação científica que abrangem os aspectos do mundo tanto observáveis como inobserváveis. Assim, segundo o realismo científico, as entidades inobserváveis postuladas pelas teorias científicas bem-sucedidas têm existência real e essas teorias são verdadeiras ou aproximadamente verdadeiras, no sentido correspondencial ou minimalista da verdade. As teorias devem ser interpretadas literalmente e as entidades inobserváveis por elas postuladas pertencem à realidade como parte constituinte de seu "mobiliário" e não servem apenas como "peças" de um quebra-cabeça teórico que visa a "salvar os fenômenos".

Embora reconheçamos o trabalho hercúleo de pensadores como Bunge (1976, p. V), que, sem perder a sintonia com o conhecimento e a tecnologia atuais, procura fazer uma genuína revisão histórica, na tentativa de oferecer uma fundamentação ao realismo científico, haja vista sua convicção de que "o objetivo último da investigação teórica, seja na filosofia, ciência ou matemática, é a elaboração de sistemas, ou seja, de teorias", limitamo-nos aqui à tarefa mais modesta de analisar criticamente a pertinência do argumento do milagre, frente à defesa do realismo científico, tal como caracterizado acima.

Apesar das diferenças apresentadas pelas diversas formulações do realismo científico, o argumento do milagre ${ }^{2}$ aparece como principal estratégia de defesa realista contra os ataques antirrealistas científicos (do positivismo lógico, instrumentalismo, empirismo construtivo, historicismo, construtivismo social, pragmatismo etc.). Em geral, trata-se de uma inferência da melhor explicação, a qual permite justificar a escolha da hipótese que proporciona a melhor explicação. Esse argumento pode ser formulado de diversas maneiras. De acordo com uma de suas versóes clássicas, constitui um fato empírico in-

\footnotetext{
2 O argumento do milagre, a partir da década de 1970, ganha versōes cada vez mais sofisticadas na dinâmica do desenvolvimento filosófico e também sofre denominações diferenciadas nesse processo. É chamado, por exemplo, de argumento do sucesso, argumento do não-milagre ou sem milagres, argumento último, argumento explicacionista realista. Psillos (1999) o denomina argumento PutnamBoyd, porque Putnam (1975) o formula, apoiando-se em algumas consideraçóes feitas por Boyd, em sua defesa do realismo científico. Para fins de clareza, será adotada neste artigo apenas a terminologia "argumento do milagre".
} 
dubitável que a ciência é bem-sucedida em fazer previsóes precisas, explicar acuradamente, controlar a natureza etc. Esse é um fato que requer explicação. $\mathrm{O}$ realismo científico é a melhor hipótese capaz de explicar o sucesso instrumental da ciência. Se há tais entidades inobserváveis, como os elétrons, então uma "explicação natural" do sucesso empírico das teorias que falam de elétrons é que eles existem na realidade e que essas teorias são abordagens pelo menos parcialmente verdadeiras de como eles se comportam. Negar a existência dessas entidades seria fazer do sucesso da ciência algo miraculoso. Nesse contexto, o problema a ser investigado neste artigo pode ser assim sintetizado: na defesa do realismo científico, o argumento do milagre se apresenta como um meio adequado de escolha racional da hipótese que proporciona a melhor explicação para o sucesso da ciência? Entendemos que o argumento do milagre continua sendo estratégico na defesa do realismo científico. No entanto, consideramos que tal argumento precisa de uma série de qualificaçóes, levando a uma versão mais fortalecida, sistêmica, articulada, para que possam ser oferecidas respostas adequadas às objeçôes que lhe são dirigidas.

\section{Notas SObRe O ARGUMENTO DO MILAGRE}

Putnam, reconhecidamente, é um pensador crítico, que póe em prática, de fato, a discussão racional, a disputa de ideias, como forma de aprimoramento do conhecimento. Com efeito, ao examinarmos o pensamento de Putnam, notamos um desenvolvimento a partir da superação de suas próprias teses. Não obstante as significativas mudanças de posicionamento, o tema norteador de sua obra permanece sendo o realismo, expresso em três fases mais nitidamente distintas: o realismo metafísico, o realismo interno e o realismo natural. Em cada uma delas, Putnam reservou um lugar de defesa, especificamente, para a intuição realista científica, apoiando-se em alguma versão do argumento do milagre (SOUZA, 2013).

O argumento do milagre, tal como formulado por Putnam (1975), é uma instância da inferência da melhor explicação ou abdução. Para Putnam (1975, p. 73), “[o] argumento positivo para o realismo [científico] é que ele é a única filosofia que não faz do sucesso da ciência um milagre”. Daí esse argumento ficar conhecido como o argumento do milagre.

Sugerimos a seguinte estruturação desse argumento, que envolve variantes das afirmaçóes abaixo, nas quais E são as premissas evidenciais disponíveis (os dados, os fatos) e $\mathrm{H}$ as hipóteses explicativas: 
$\mathrm{E}_{1}$ : As teorias científicas são bem-sucedidas empiricamente.

$\mathrm{E}_{2}$ : Considera-se uma teoria bem-sucedida empiricamente aquela que conseguir explicar com detalhes e prever com acuidade os fenômenos naturais a que se aplicam.

$\mathrm{E}_{3}$ : Deve haver uma explicação para o fato de as teorias científicas serem bem-sucedidas empiricamente.

$\mathrm{E}_{4}$ : 'Ser verdadeiro' denota uma relação de correspondência extrateórica entre as teorias e o mundo (concepção da verdade como correspondência).

$\mathrm{E}_{5}$ : Se as teorias científicas forem verdadeiras, serão bem-sucedidas empiricamente.

$\mathrm{E}_{6}$ : $\mathrm{O}$ sucesso do empreendimento científico pode ser explicado, se considerarmos que as teorias científicas aceitas são pelo menos aproximadamente verdadeiras.

$\mathrm{E}_{7}$ : As tentativas de explicar o êxito da ciência, em termos não-realistas, são insatisfatórias e fazem deste um milagre.

$\mathrm{E}_{8}$ : Não parece razoável identificarmos o sucesso do empreendimento científico com um milagre.

$\mathrm{H}_{1}$ : Assim, resta-nos como única explicação para o êxito da ciência a hipótese de que nossas melhores teorias científicas vigentes são pelo menos aproximadamente verdadeiras: a ciência é bem-sucedida porque o que ela diz corresponde de perto à realidade e, assim, as entidades inobserváveis utilizadas nas hipóteses explicativas (aproximadamente verdadeiras) da ciência têm existência real, povoam a realidade.

$\mathrm{E}_{9}$ : $\mathrm{O}$ realismo científico propóe as teses de que as afirmaçóes da ciência são verdadeiras ou pelo menos aproximadamente verdadeiras, e de que, sendo assim, as entidades inobserváveis postuladas pelas teorias científicas de fato existem.

$\mathrm{H}_{2}$ : $\mathrm{O}$ realismo científico é a doutrina filosófica da ciência adequada porque oferece a única explicaçáo satisfatória da ciência e da atividade científica. 
Essa versão do argumento do milagre apresenta uma fragilidade: qualquer formulação de uma explicaçáo alternativa coerente para o sucesso da ciência seria suficiente para bloquear a conclusão de Putnam (1975). Uma versão mais robusta do argumento, como as apresentadas por Leplin (1984) e Boyd [(1983) 1984], é que a verdade (ou a verossimilhança) é a melhor explicação para o sucesso científico.

Segundo Boyd (2002), o realismo científico é uma concepção intuitiva a respeito da ciência e da prática científica. Entende-se que a pesquisa científica produz conhecimento de fatos, em grande medida, independentes da teoria. Tal conhecimento é possível (de fato, real) mesmo naqueles casos nos quais os estados de coisas relevantes não são observáveis. Dessa perspectiva, desde que se reconheça a falibilidade dos métodos científicos e que a maioria do conhecimento científico é apenas aproximada, se está justificado a aceitar as mais seguras descobertas científicas em seu valor de face.

A discussão aqui não constitui simplesmente uma disputa conceitual sobre a interpretação das teorias científicas. Para Boyd, é um fato contingente e testável empiricamente que as teorias científicas podem resultar, e de fato resultam, em verdades aproximadas.

O argumento do milagre, na versão naturalista de Boyd [(1983) 1984], enfoca a metodologia científica. Todos os aspectos da metodologia científica são profundamente carregados de teoria. Essencialmente, a metodologia científica é quase linearmente dependente das teorias de fundo aceitas. Essas teorias fazem os cientistas adotarem, desenvolverem ou modificarem seus métodos de interaçáo com o mundo e os procedimentos que eles usam para tomar medidas e testar teorias. Os cientistas usam teorias de fundo aceitas para formar suas expectativas, escolher os métodos relevantes a fim de testar teorias, inventar experimentos, criar e regular instrumentos, acessar a evidência experimental, escolher entre teorias rivais, adicionar hipóteses sugeridas etc.

A melhor explicaçáo da confiabilidade instrumental da metodologia científica é que as teorias de fundo são, de modo relevante, aproximadamente verdadeiras. As teorias científicas maduras são aproximadamente verdadeiras, pelo menos no que diz respeito aos aspectos relevantes para o seu sucesso instrumental. Essas teorias científicas de fundo foram elas próprias alcançadas por raciocínio abdutivo, seguido de teste com outros fenômenos. Consequentemente, é razoável acreditar que o raciocínio abdutivo seja confiável: ele tende a gerar hipóteses aproximadamente verdadeiras. Essa conclusão não constitui uma ver- 
dade a priori. A confiabilidade do raciocínio abdutivo é uma afirmação empírica e, se verdadeira, será contingentemente verdadeira. De fato, o argumento do milagre afirma que a melhor explicação de que a metodologia científica tem o aspecto contingente de produzir previsões corretas é que as teorias implicadas nessa metodologia são, de forma relevante, aproximadamente verdadeiras.

Na primeira fase de sua trajetória intelectual, Putnam (1975) mantém, subjacente a sua defesa do realismo científico, a teoria da verdade como correspondência, conforme podemos observar acima, na apresentaçáo do argumento do milagre e, mais especificamente, $\mathrm{em}_{4}$, esposando em última instância o que ele veio posteriormente chamar (e repudiar) de realismo metafísico.

Dois pontos importantes são esclarecidos por Putnam [(2010) 2012]. Primeiro, embora o realismo metafísico esteja subjacente a sua defesa do realismo científico (e também de seu realismo de senso comum e matemático), 'realismo metafísico' nunca fora por ele utilizado como sinônimo de 'realismo científico'. Segundo, em Realism and reason - palestra descrita como o "manifesto" de seu período realista interno - Putnam (1976) usa 'realismo interno' em dois sentidos diferentes: (1) 'realismo científico' e (2) 'verificacionismo sofisticado'. $\mathrm{O}$ realismo interno ${ }_{1}$, enquanto realismo científico, é uma hipótese empírica, ou seja, uma explicação da ciência do sucesso da ciência; e ele é interno no sentido de interno à ciência. $\mathrm{O}$ realismo interno ${ }_{2}$, enquanto 'verificacionismo sofisticado', consiste na perspectiva geral da palestra que, a partir de então, é mantida por aproximadamente treze anos como a posição filosófica de Putnam, segundo a qual verdade e verificabilidade idealizada supostamente coincidem.

Assim, na segunda fase do pensamento putnamiano, o seu realismo interno ${ }_{2}$, descrito por Putnam (1981) como a antítese do realismo metafísico, é a posição de um antirrealista sobre a verdade (correspondencial) e, ao mesmo tempo, de um anti-instrumentalista sobre teorias cientificas que, com o apoio do argumento do milagre, defende o realismo interno ${ }_{1}$ ou científico, de modo que a explicação do sucesso do método científico não seja ignorada ou considerada como sem sentido ou desnecessária pela semântica verificacionista do internalismo.

A terceira fase do pensamento putnamiano, denominada realismo natural, é marcadamente um balanço do realismo metafísico inicial e do realismo interno de seu período intermediário (SOUZA, 2013), sendo apresentada por Putnam [(1990) 1992], inicialmente, nas Gifford Lectures. O realismo científico, defendido via argumento do milagre, continua a fazer parte da agenda de 
Putnam (1999, p. 10), com o diferencial de que, agora, em um contexto em que interfaces entre mente/linguagem e mundo são prescindidas, a favor da ideia de que, em se tratando de percepção ou mesmo de concepção, "as nossas capacidades cognitivas [...] conseguem chegar [diretamente] aos próprios objetos". Se, tradicionalmente, há uma forte tendência em considerar conceitos (ideias) como certo tipo de entidades mentais (imagens) que correspondem a coisas do mundo exterior, da perspectiva do realismo natural, diferentemente, possuir um conceito é ter uma habilidade e não a posse de uma imagem mental, entendendo esta como representação, impressão, sensação, experiência, dado do sentido, qualia ou o que quer que seja. Essa habilidade se manifesta, em especial, na compreensão e utilização de expressôes com sentido.

Tendo em vista o nosso objetivo, o qual consiste em analisar, de uma maneira geral, a relevância do argumento do milagre para o realismo científico, não nos dedicamos aqui a um exame detido do pensamento putnamiano, distinguindo cada uma de suas fases, mas apenas destacamos a permanência e pertinência desse argumento, não obstante as, rapidamente citadas, significativas mudanças de abordagens filosóficas efetuadas por Putnam ao longo de sua trajetória intelectual realista.

\section{Críticas E DEFeSAS do aRGUMENTO DO MILAGRE}

Nem todos, porém, compartilham da imagem realista de ciência, exposta sumariamente acima. Há muita discordância entre os filósofos acerca dos objetivos da ciência, em que consiste o êxito científico, se precisa ou não ser explicado (e, se necessário explicar, como pode ser explicado) e, mesmo dentre os realistas, pergunta-se qual é o papel do realismo, da verdade e do argumento do milagre, nessa explicação. Os exemplos de críticas e defesas do argumento do milagre aqui apresentados não são exaustivos, mas são paradigmáticos da forma em que essa discussão pode assumir.

Nesse contexto, o argumento antirrealista conhecido como metaindução histórica [discutida por Putnam, (1976) 1978] ou indução pessimista [desenvolvida por Laudan, (1981) 1984] destaca-se como reação ao argumento do milagre e, em geral, ao otimismo epistemológico do realismo científico.

De acordo com Laudan [(1981) 1984], a própria história da ciência apresenta evidências contrárias à postura de otimismo epistemológico do realismo científico, ou, tomando emprestada sua terminologia, ao "realismo 
epistemológico convergente". Teorias científicas que, por algum tempo, foram consideradas bem-sucedidas empiricamente revelaram-se falsas posteriormente e os termos teóricos presentes nessas teorias mostraram não ter referentes reais. Assim, inferimos que, se a ciência contemporânea mostra que a maioria das teorias passadas estava errada, entáo, exatamente ao contrário do que prega o realista científico, os termos teóricos centrais dessas teorias científicas não fazem referência a entidades reais e, portanto, essas teorias não podem ser aproximadamente verdadeiras.

Laudan [(1981) 1984] apoia seu argumento da indução pessimista listando casos históricos de teorias empiricamente bem-sucedidas e frutíferas que acabaram se mostrando nem verdadeiras nem referenciais. Um desses casos é a teoria do calórico. Essa teoria foi considerada bem-sucedida durante muito tempo. Conseguia explicar o fenômeno natural do calor, postulando a existência de uma substância fluida, o calórico, que seria a causa da elevação e queda da temperatura dos corpos. Mas, como ilustra Laudan [(1981) 1984], com o desenvolvimento da termodinâmica, essa teoria se revelou falsa. Essa mudança teórica descartou a hipótese da existência de uma entidade de espécie natural à qual o termo 'calórico' supostamente se referiria.

A partir da indução pessimista, é possível concluir também, contra o argumento do milagre, que, se as teorias bem-sucedidas têm sido regularmente comprovadas como falsas, então, o sucesso de uma teoria não pode servir de evidência de que ela é verdadeira.

Opondo-se a esse argumento, Leplin $(1997,2006)$, dentre outros, procura defender o realismo científico da crítica da indução pessimista. A lista de Laudan [(1981) 1984] de teorias proeminentes no passado, mas cujas postulaçôes inobserváveis são inaceitáveis do ponto de vista da ciência contemporânea, embora cause certo inconveniente para os realistas científicos, não é generalizável. O período histórico do qual Laudan [(1981) 1984] compila sua lista de exemplos é favorável a seu propósito, mas indevido para sustentar o alcance pretendido da indução pessimista.

Realistas científicos, como Putnam (1975) e Boyd [(1983) 1984], restringem seu argumento abdutivo à ciência madura. ${ }^{3}$ Isso desqualifica os exemplos de Laudan [(1981) 1984]. Assim, o argumento da indução pessimista se apoia em uma premissa falsa: a história da ciência madura não

\footnotetext{
${ }^{3}$ A dificuldade está em caracterizar a ciência madura de uma forma que não seja "escandalosamente ad hoc".
} 
é marcada por mudanças teóricas radicais. Ao contrário, segundo Boyd [(1983) 1984, p. 41-42],

o progresso histórico das ciências maduras é em grande medida uma questáo de aproximaçóes da verdade sucessivamente mais acuradas sobre tanto os fenômenos observáveis como os inobserváveis. As teorias posteriores comumente são construídas em cima do conhecimento (observacional e teórico) das teorias precedentes.

E, como observa Leplin (2006, p. 694),

o realista pensa não apenas que as melhores teorias confirmadas são pelo menos parcialmente verdadeiras, mas também que os métodos de teorizar e de proteger [a teoria] de erro melhoraram com a experiência científica. É um corolário natural da posição realista que a verdade é mais frequente entre as teorias correntes do que entre as passadas.

Além disso, segundo Leplin (2006, p. 693-694), "mesmo se muitas teorias bem-sucedidas forem falsas, o sucesso pode ainda indicar a verdade se sua frequência entre as teorias falsas for baixa”.

Uma pergunta ainda pode ser feita a Laudan: para negar a existência de entidades teóricas precedentes, assume-se a perspectiva contemporânea, contudo, assumir essa perspectiva não é o mesmo que declarar a ciência corrente como verdadeira e referencial?

Consideramos, por fim, outra resposta ao argumento da indução pessimista, que pode ser tirada da proposta de "uma nova defesa do realismo científico" de Leplin (1997). Leplin (1997) soma ao argumento do milagre o argumento da "novidade preditiva".

Para Leplin (1997), a previsão bem-sucedida de resultados empíricos novos pode ser explicada apenas por atribuir verdade, em alguma medida pelo menos, às teorias que produzem tais previsôes. Além disso, as abordagens não-realistas não conseguiriam acomodar o fenômeno do "sucesso novo", ao passo que a abordagem realista explica satisfatoriamente a novidade preditiva.

Segundo Leplin (1997), náo se pode explicar, satisfatoriamente, como as teorias começam a funcionar fora do seu campo de aplicaçáo inicial, sem pressupor que as entidades que elas postulam existem de fato e que essas teorias são pelo menos aproximadamente verdadeiras, ou seja, sem recorrência a uma postura tipicamente realista científica. Enquanto a teoria funciona para 
o que foi projetada desde o início, enquanto explica e prevê os fenômenos aos quais foi destinada a explicar e prever, pode-se alegar que ela é bem-sucedida exatamente porque foi feita para isso. Todavia, quando ela passa a funcionar em outros campos de aplicação, a explicação realista parece ser a única explicação satisfatória disponível.

Assim, fica evidente outra falha do argumento de Laudan [(1981) 1984]: ele opera com uma noção de sucesso empírico mais fraca do que a ideia de sucesso preditivo novo. É um equívoco creditar sucesso aos exemplos de Laudan [(1981) 1984], nos termos de Leplin (2006).

A proposta de Leplin será retomada posteriormente porque, além de oferecer uma resposta à crítica de Laudan [(1981) 1984], é uma maneira de fortalecer o argumento do milagre. Tendo em vista uma versão fortalecida do argumento do milagre, propomo-nos a decidir quanto ao seu papel na defesa do realismo científico.

Outra crítica que se destaca contra o argumento do milagre foi elaborada por Fine (1984), a partir do argumento da circularidade viciosa. De acordo com Fine (1984), o argumento explicacionista a favor do realismo científico consiste em uma inferência que parte do reconhecimento do sucesso do empreendimento científico para a conclusão de que é correta uma abordagem realista da prática científica.

Centrando a atenção no empreendimento científico global, o realista desafia: como a metodologia científica (dependente das teorias aceitas), que essencialmente pressupóe a existência de entidades inobserváveis, pode garantir o sucesso empírico da ciência, a não ser pela real existência dessas entidades inobserváveis?

Fine (1984, p. 89) observa que a metodologia científica não é feita apenas de sucesso, ao contrário: há muitos fracassos ${ }^{4}$. Assim, o que de fato requer explicação não é o sucesso da ciência, mas "o sucesso ocasional de uma estratégia que costumeiramente fracassa". Em outras palavras, os resultados bem-sucedidos do empreendimento científico são significativos e inegáveis, como também o são os inúmeros fracassos provenientes do mesmo procedimento. Nesse

\footnotetext{
${ }^{4}$ Para Paul Feyerabend (1975), é comum na literatura serem frisadas apenas as realizaçóes bemsucedidas da ciência, deixando de lado os seus fracassos. Porém, de fato, quando considerada na sua integridade, a história da ciência é uma história de fracassos. Ele sugere que o êxito pode ser em parte explicado porque o cientista dirige o seu esforço e atenção para os problemas mais fáceis de serem resolvidos.
} 
sentido, a seguinte questáo pode ser levantada: por que exatamente os mesmos métodos produzem um histórico catastrófico de fracassos e, ocasionalmente, também um padrão de sucessos? Como, por meio de procedimentos associados a um fundo de fracassos, emerge, algumas vezes, o sucesso?

A saída de realistas, como Boyd [(1983) 1984], é dizer que as teorias de fundo aceitas são pelo menos aproximadamente verdadeiras, o que possibilitaria o êxito do empreendimento científico, não obstante os fracassos ocasionais. Entretanto, como observa Fine (1984), o recurso à verdade aproximada das teorias de fundo náo resolve o problema porque é preciso, então, explicar como essas teorias teriam emergido.

Outra alternativa seria recorrer à legitimidade da abdução. Segundo Psillos (1999), o argumento do milagre é um argumento filosófico que procura defender a confiabilidade da metodologia científica em produzir teorias e hipóteses aproximadamente verdadeiras, apoiando-se, porém, em um tipo de raciocínio explicativo que ocorre frequentemente na ciência: a abdução. Instâncias bem-sucedidas desse raciocínio fornecem a base para esse argumento abdutivo mais geral da filosofia. Em um primeiro momento, o raciocínio abdutivo envolve a afirmação de que é razoável aceitar que as teorias científicas particulares são, de um modo relevante, aproximadamente verdadeiras. Em um segundo momento, tomando por base o resultado dos raciocínios anteriores, defende-se uma afirmação mais geral: a ciência pode resultar em verdade aproximada. $\mathrm{O}$ argumento do milagre é um tipo de meta-abdução. Isso não quer dizer que o argumento do milagre seja exatamente uma generalizaçáo sobre as inferências abdutivas dos cientistas. Embora seja uma instância do método que os cientistas empregam, o argumento do milagre tem por objetivo algo maior: defender a tese de que a inferência da melhor explicação, ou seja, esse tipo de método inferencial abdutivo, é racionalmente confiável.

A despeito de o procedimento científico, de postular hipóteses e inferir sua verdade por meio da abdução e dos testes, ser prática comum na ciência e empregado por muitos realistas científicos para corroborar a sua própria doutrina, pode-se questionar a legitimidade desta última utilização. Para Fine (1984), a defesa abdutiva do realismo científico seria viciosamente circular: pressupóe o que está em questão, que precisa ser independentemente demonstrado.

Fine (1984, p. 86) analisa: 
O problema do realismo é, precisamente, se devemos acreditar na realidade daqueles indivíduos, propriedades, relaçôes, processos etc., usados nas hipóteses explicativas bem-sustentadas [da ciência]. E qual é a hipótese do realismo, como ela surge como uma explicação da prática científica? A hipótese é a de que as nossas teorias científicas aceitas são aproximadamente verdadeiras, onde se considera que "ser aproximadamente verdadeiro" denota uma relação extrateórica entre teorias e o mundo. Desse modo, para responder às dúvidas sobre a realidade das relaçóes postuladas pelas hipóteses explicativas [da ciência], o realista procede introduzindo outra hipótese explicativa (o realismo), ela própria postulando essa relação (a verdade aproximada). [...] Assim, tanto no nível fundamental como no metodológico, mostrar que o realismo é uma boa hipótese para explicar a prática científica não oferece nenhuma sustentação ao realismo. [...] essa demonstração (mesmo se bem-sucedida) meramente pressupóe a questão [begs the question] que temos deixado em aberto ("precisamos considerar uma boa hipótese explicativa como verdadeira?”).

Um argumento viciosamente circular não pode ser persuasivo, pois, de algum modo, assume, ou postula, o que precisa ser independentemente demonstrado. $\mathrm{O}$ realista, ao defender a sua doutrina, não pode assumir a validade de um princípio cuja validade é o que está em debate, sob pena de tornar sua defesa carente de qualquer força argumentativa. Assim, a defesa explicacionista do realismo náo é forte nem persuasiva o suficiente, nem fornece sustentaçáo racional para se acreditar no realismo. Dessa maneira, Fine (1984) observa que, se o realista quiser oferecer uma defesa razoável para o realismo científico, deverá mudar de estratégia e empregar um argumento mais específico para a sua defesa que não seja o abdutivo.

Fine (1984) não ignora a alegação de Boyd [(1983) 1984] de que, assim procedendo, isto é, adotando a abdução como é feito na ciência, o realista está sendo coerente com sua doutrina naturalista. O problema é que essa "coerência" envolve uma circularidade viciosa, o que é inaceitável, do seu ponto de vista.

A fim de defender o realismo científico da crítica de Fine (1984), Psillos (1999) distingue dois tipos de argumentos circulares: o argumento de premissa circular e o de regra circular. Segundo Psillos (1999), o argumento de premissa circular é aquele que, ao pretender oferecer razóes para se aceitar certa conclusão, apresenta como pelo menos uma das razóes a própria conclusão. Esse tipo de argumento é viciosamente circular.

O mero fato de que uma premissa seja idêntica à conclusão, ou uma paráfrase dela, não é suficiente para atribuir circularidade viciosa ao argumen- 
to. Para mostrar que um argumento é viciosamente circular, deve-se não apenas olhar para as sentenças utilizadas no argumento, no âmbito estrutural, mas também considerar o que o argumento presume mostrar ao usar essas sentenças específicas. Psillos (1999, p. 82) exemplifica:

Se olharmos apenas para a estrutura sentencial do argumento do tipo ' $a$ $\& b$, portanto, $b \& a$, ela é circular. Mas não é viciosamente circular se considerarmos que seu propósito é mostrar apenas a comutatividade da conjunção lógica. Similarmente, o argumento do tipo ' $p$, consequentemente $p$ ’ não é viciosamente circular se ele pretender mostrar que toda sentença é uma consequência lógica de si mesma. Mas seria viciosamente circular onde pretendesse mostrar que $p$ é verdadeira. Porque entáo pretenderia provar que $p$ é verdadeira onde apenas assume que $p$ é verdadeira.

Na concepção de Psillos (1999), existe também outro tipo de argumento em que há circularidade, mas não viciosa. É o caso no qual a regra é circular, e não a premissa. Isso acontece quando o próprio argumento é uma instância da regra de inferência vindicada pela conclusão, ou envolve essencialmente uma aplicação da regra de inferência defendida pela conclusão. Conforme Psillos (1999, p. 82-83), esse é o caso do argumento do milagre (AM), cujas premissas

asseveram a impregnação teórica da metodologia científica e seus sucessos instrumental e preditivo amplamente aceitos. Então, por meio de uma meta-IME [meta-inferência da melhor explicação], o argumento conclui que as teorias de fundo são aproximadamente verdadeiras. Uma vez que, comumente, essas teorias aproximadamente verdadeiras são obtidas por meio de IME de primeira ordem, esta informação, juntamente com a conclusão da meta-IME, implica que IME é confiável. Assim, a verdade da conclusão do AM é (parte de) uma condição suficiente para aceitar que IME é confiável. O AM não é claramente [um argumento] de premissa circular. A conclusão da meta-IME (que teorias são aproximadamente verdadeiras) não está entre as premissas do argumento. De fato, nenhuma suposição sobre a verdade aproximada de teorias é feita nas premissas, explícita ou implicitamente. Além disso, não há garantia a priori de que a conclusão do AM será, necessariamente, a de que as teorias sáo (aproximadamente) verdadeiras, como certamente haveria se este argumento fosse de premissa circular. A conclusão é verdadeira se, afinal, for a melhor explicação das premissas, mas ela poderia não ser a melhor explicação. [...] este ponto é implicitamente concedido pelos críticos do AM, uma vez que eles se esforçam para argumentar que há explicaçóes melhores para o sucesso da ciência. Ao argumentar que a conclusão do AM não precisa ser a conclusão realista pretendida, eles reconhecem implicitamente que o AM não é [um argumento] de premissa circular. 
Tendo buscado mostrar que o argumento do milagre é um argumento de regra circular e não de premissa circular, parte da estratégia de Psillos (1999) é procurar eliminar a suspeita de que os argumentos de regra circular são viciosos, no sentido de assumirem a confiabilidade da regra adotada. Se essa suposição for baseada na aceitação prévia da conclusão do argumento de regra circular, então os proponentes de um argumento de regra circular, ao que parece, trafegariam em um círculo vicioso. Eles teriam que provar a conclusão antes de aceitarem a regra usada para derivá-la.

Psillos (1999) nega que quaisquer suposições sobre a confiabilidade de uma regra estão presentes, explícita ou implicitamente, quando uma instância dessa regra é usada. Nem deveria a confiabilidade da regra ser estabelecida antes de alguém ser capaz de usá-la de um modo justificável:

Quaisquer suposiçóes que precisam ser feitas sobre a confiabilidade da regra de inferência, sejam elas implícitas ou explícitas, não importam para a correção da conclusão. Consequentemente, sua defesa não é necessária para a correção da conclusão. (PSILLOS, 1999, p. 83)

Dessa forma, Psillos (1999) acredita estar apto a concluir que, no caso do argumento de regra circular, não há vício e, sendo o argumento do milagre um argumento de regra circular, e não de premissa, não é vicioso, apesar da circularidade que envolve.

Em consonância com Psillos (1999), na perspectiva naturalista, adotada por Boyd [(1983) 1984], admite-se, explícita ou implicitamente, que a inferência da melhor explicação pode ser utilizada tanto pelos cientistas como pelos realistas científicos. $\mathrm{O}$ cientista, em geral, adota a abduçáo em suas pesquisas para escolher uma hipótese explicativa para um fato novo ou anomalia. $\mathrm{Na}$ filosofia, o epistemólogo pode utilizá-la para sustentar tanto a crença na verdade aproximada da ciência como a confiabilidade dos métodos científicos e, como extensão, corroborar a sua postura filosófica, mediante inferências como o argumento do milagre.

No plano científico, o raciocínio abdutivo é usado para eleger a hipótese explicativa de um determinado fenômeno. A justificação da legitimidade desse procedimento viria do poder explicativo e preditivo das teorias científicas que o empregam, dentre outros possíveis critérios de aceitabilidade racional ou desideratos das teorias científicas. Quando um cientista infere abdutivamente a existência de uma entidade inobservável, como as partículas subatômicas, 
para explicar um determinado fenômeno, o que legitima esse procedimento é a resistência a testes empíricos rigorosos no domínio da teoria. Da mesma maneira, no plano filosófico, o realista deve oferecer uma justificativa razoável para a aceitação do raciocínio abdutivo, empregado na defesa do realismo científico.

\section{O PRINCÍPIO DA CARIDADE}

Putnam [(1976) 1978, p. 25] apresenta a meta-indução histórica que representa um desafio ao argumento do milagre e ao otimismo epistemológico em geral: "Assim como nenhum termo usado na ciência de mais de cinquenta anos atrás referiu, também vai se revelar que nenhum termo usado agora (com exceção, talvez, dos termos de observação, se houver) se refere."

Se a ciência muda constantemente de opinião sobre muitas coisas, então, por que alguém deve ser um "realista" de qualquer tipo sobre as suas conclusóes? E se alguém diz que a maioria das "conclusôes" científicas é, pelo menos, aproximadamente verdadeira, então, quais são os critérios pelos quais podemos determinar quão boa é a aproximação?

Nas palavras de Putnam [(2010) 2012, p. 105]:

Naturalmente, o problema torna-se ainda pior ao se concordar com Eddington de que a mesa do leigo náo existe de fato (isso porque a física mostrou que as mesas consistem principalmente de espaço vazio) e com Sellars de que a imagem manifesta é falsa (outra maneira de dizer a mesma coisa). Mesmo se "a mesa científica" realmente existir, como Eddington pensava, a pessoa comum nada sabe sobre "a mesa científica". Assim, nada do que essa pessoa fala existe de fato, se Eddington e Sellars estiverem certos! E se os físicos de cada século têm uma "imagem" diferente da mesa, então, a "mesa científica" dos séculos anteriores não existe realmente tampouco!

Para responder a esse desafio cético, Putnam [(1976) 1978, p. 22-25; (2010) 2012, p. 105-106] lança mão do que é conhecido como o princípio da caridade ou princípio do beneficio da dúvida. O princípio da caridade exige que interpretemos, por exemplo, o termo "sólido" de tal forma que a descoberta de que mesas consistem principalmente de espaço vazio não seja incompatível com dizer que a maioria das mesas é sólida. Tendo em vista a história da ciência, podemos notar que a maior parte dos próprios físicos aplicou, 
automaticamente, o princípio da caridade e não adotou o ponto de vista de Eddington-Sellars.

Com efeito, as "imagens" associadas à física de um século são muitas vezes incompatíveis com as imagens associadas com a do próximo século, mas, de acordo com Putnam [(2010) 2012, p. 106], não temos que aceitar a chamada "meta-indução pessimista", concluindo que todas as teorias científicas, mais cedo ou mais tarde, se revelam completamente falsas.

Salienta Putnam [(2010) 2012, p. 106]:

Não aceitamos a imagem do espaço euclidiano ou do tempo como absoluto, mas, é sabido que nós normalmente traçamos trajetórias, até mesmo as trajetórias dos satélites, empregando a física newtoniana. E podemos fazer isso porque as explicaçóes Newtonianas podem facilmente ser reformuladas em termos relativistas (quando as velocidades não são demasiado grandes etc.). Neste sentido, a física newtoniana é robusta; é "aproximadamente verdadeira”, e a física mais recente diz-nos exatamente quão boa é a aproximação.

Todavia, podemos dizer que uma teoria é aproximadamente verdadeira antes de termos uma teoria recente que nos diga quão boa é a aproximação?

De acordo com Putnam [(2010) 2012, p. 106], sim, e Newton certamente pensava assim:

Ele não só não afirmou que a sua teoria da gravitação era perfeitamente precisa; como também especulou que, por exemplo, a potência "2" da famosa lei do inverso do quadrado poderia ser apenas um valor aproximado, e ele também enfatizou que sua "teoria da açáo a distância" poderia ser substituível por uma teoria da "ação local" quando tivéssemos mais conhecimento. Dizer que o conceito de 'aproximadamente verdadeiro' deve ser feito matematicamente preciso ou, entâo, ser descartado é, penso eu, uma forma de cientificismo.

Como observa Philip Kitcher (1993, p. 96), "as mudanças conceituais na ciência $[. .$.$] podem ser entendidas, e entendidas como progressivas,$ reconhecendo-as como envolvendo melhorias nos potenciais de referência de termos-chave". Assim, um realismo falibilista é uma postura defensável e defendida com razoabilidade. E, independentemente de se ter ou não ter um "critério" para a determinação do grau de aproximação da verdade das teorias científicas, continuamos produzindo teorias, como a física newtoniana, as 
quais funcionam por serem aproximada ou parcialmente verdadeiras, considerando o princípio da caridade.

A realidade, de alguma forma, restringe a ciência. Não é apenas porque a aerodinâmica é coerente com nosso sistema de crenças, nem porque acreditamos que nossas afirmaçóes sejam publicamente revisáveis que os avióes voam, por exemplo. De acordo com Putnam [(2010) 2012], é um fato que aviōes nos habilitam a viajar longas distâncias rapidamente.

Pode ser argumentado, porém, que a aerodinâmica pode estar baseada na mecânica clássica (newtoniana) que é estritamente falsa (não pode ser aplicada a velocidades relativísticas, isto é, a velocidades muito altas ou a "massas" muito pequenas, objeto da mecânica quântica), não obstante suas leis serem suficientes para regrar uma aplicação bem-sucedida, por exemplo, colocar um avião em voo.

Daí a importância de o realista científico manter que essa teoria funciona como um caso-limite para teorias mais desenvolvidas. Mesmo que a teoria em si não seja verdadeira, há alguns aspectos dela que são verdadeiros, próximos da verdade ou parcialmente verdadeiros. Outro passo importante para a construção da defesa realista é ser capaz de identificar quais são esses aspectos que conduzem a certa confiabilidade epistêmica da teoria.

Como visto anteriormente, segundo Leplin (2006), as partes da teoria que são dignas do compromisso realista são aquelas essenciais para a derivação de previsão nova. Na concepção de McMullin (1984), por sua vez, são as responsáveis pela fecundidade teórica.

Já para Psillos (1999) é suficiente mostrar que os mecanismos e leis teóricas que geraram o sucesso das teorias passadas são retidos em nossa imagem científica atual ou, dito de outra maneira, que o sucesso das teorias passadas não dependeu de seus componentes falsos, mas sim dos verdadeiros.

A partir da análise da proposta realista científica de Boyd, Putnam [(1976) 1978, p. 19; 21] desenvolve uma discussão sobre a relação do sucesso da ciência com a teoria da verdade como correspondência ("ou qualquer outra teoria da verdade"). Os cientistas agem da forma como agem porque acreditam que "(1) os termos de uma ciência madura comumente referem" e que "(2) as leis de uma teoria pertencente a uma ciência madura são comumente aproximadamente verdadeiras". E sua estratégia, por sua vez, funciona porque essas suas crenças - (1) e (2) - são verdadeiras. Assim, 
as noções de 'verdade' e 'referência' têm um papel causal-explicativo na epistemologia. (1) e (2) são premissas em uma explicação do comportamento dos cientistas e do sucesso da ciência [...]. Substituir o 'verdadeiro' na premissa (2) [...] por algum 'substituto' operacionalista - e.g. 'é simples e conduz a predições verdadeiras' - não preservará a explicação. (PUTNAM, [1976] 1978, p. 21).

Putnam [(1976) 1978, p. 21-22] pede para supormos que $T_{1}$ seja uma teoria de uma ciência madura, por exemplo, de alguma parte central da física e que, enquanto cientistas, estamos procurando uma teoria $T_{2}$ para substituir $\mathrm{T}_{1}$ que, em algumas áreas, conduz a prediçóes falsas. Se acreditarmos nos princípios (1) e (2), saberemos que as leis de $T_{1}$ são, provavelmente, aproximadamente verdadeiras. Logo, deve ser uma propriedade de $T_{2}$ que as leis de $T_{1}$ sejam aproximadamente verdadeiras quando julgadas da perspectiva de $\mathrm{T}_{2}$. Caso contrário, $\mathrm{T}_{2}$ náo teria a chance de ser verdadeira. Uma vez que queremos teorias que não sejam apenas aproximadamente verdadeiras, mas que tenham a chance de ser verdadeiras, consideraremos apenas como candidatas a $\mathrm{T}_{2}$ as teorias que tenham essa propriedade, ou seja, as teorias que contenham as leis de $T_{1}$ como um caso-limite. Isso significa que o reconhecimento da verdade de (1) e (2) nos capacita a restringir a classe de teorias candidatas que teremos que levar em conta e, desse modo, há um aumento da chance do sucesso. Mas, por outro lado, se tudo que sabemos é que $\mathrm{T}_{1}$ conduz a prediçôes verdadeiras em algum vocabulário observacional, então, tudo que sabemos de $\mathrm{T}_{2}$ é que ela deve implicar a maioria das "sentenças de observação" implicadas por $T_{1}$. Mas não se segue que deva implicar a verdade das leis de $\mathrm{T}_{1}$ em algum limite. Não há qualquer razáo pela qual $\mathrm{T}_{2}$ teria a propriedade de nos permitir apontar os referentes dos termos de $T_{1}$ da perspectiva de $T_{2}$. Acontece que, para o realista científico, é um fato que, da perspectiva da teoria da relatividade, podemos atribuir um referente ao "campo gravitacional" da teoria newtoniana. Essa referência retrospectiva depende do princípio da caridade.

Se acreditarmos que os termos de $T_{1}$ têm referentes, e admitirmos o princípio da caridade, haverá uma restrição sobre $\mathrm{T}_{2}$ (que estreitará a classe das teorias candidatas): $\mathrm{T}_{2}$ deve ter a propriedade de que, de sua perspectiva, se possa atribuir referentes aos termos de $T_{1}$. No entanto, se náo usarmos as noçôes de "verdade" e de "referência", mas apenas de "simplicidade" e "conduz a previsôes verdadeiras", então, não teremos qualquer coisa análoga a essa restrição, ou seja, não seremos capazes de limitar a classe das teorias candidatas. 
O princípio da caridade é exemplificado por Putnam [(1976) 1978, p. 24] da seguinte maneira: apesar de não haver nada no mundo que se ajuste exatamente à descrição de Bohr-Rutherford de um elétron, existem partículas que se ajustam aproximadamente a essa descrição. "Elas têm a carga correta, a massa correta e são responsáveis pelos efeitos-chave que Bohr-Rutherford explicaram em termos de 'elétrons'." Segundo o princípio da caridade, podemos considerar que Bohr estava se referindo a essas partículas. "A corrente elétrica de um fio é o fluxo destas partículas."

Tanto é assim que Bohr, em concordância com o princípio da caridade, continuou a usar o termo "elétron" quando, nos anos de 1930, participou da invenção da mecânica quântica, deixando para trás o período Bohr-Rutherford. Temos, por conseguinte, diferentes teorias da mesma entidade que Bohr denominou "elétron".

Mas, segundo Putnam [(1976) 1978], não podemos, apoiados no princípio da caridade, salvar a referência do flogisto, por exemplo. O limite da aplicação desse princípio é a razoabilidade: devemos poder identificar um ajuste, mesmo que aproximado, o qual indique a permanência de referência, como no caso do elétron citado acima.

Kitcher (1993), no entanto, entende que o princípio da caridade pode ser estendido, de modo a bloquear a indução pessimista, inclusive em casos como o da teoria do flogisto.

Para tanto, Kitcher (1993, p. 149) distingue dois tipos de postulaçóes introduzidas pela prática científica: postulaçóes que funcionam (working posits) e postulaçóes pressuposicionais (presuppositional posits). "A moral da história de Laudan não é que a postulação teórica em geral é duvidosa, mas que as postulaçôes pressuposicionais são suspeitas.” Enquanto as postulaçóes que funcionam são "os supostos referentes de termos que ocorrem nos esquemas de solução de problemas", as postulações pressuposicionais são "aquelas entidades que aparentemente devem existir se as instâncias dos esquemas têm de ser verdadeiras".

Como exemplo de postulação pressuposicional, Kitcher (1993, p. 149) cita o éter, que raramente foi empregado na explicação ou previsão, nunca foi sujeito à mensuração empírica e, contudo, aparentemente, deveria existir, se as afirmaçóes sobre as ondas eletromagnéticas e de luz fossem verdadeiras: 
Contraste o éter com as postulações que funcionam da ciência teórica que são referidas e caracterizadas diretamente em esquemas bem-sucedidos: átomos, moléculas, genes, campos eletromagnéticos e assim por diante. Em alguns casos, até mesmo concebemos inúmeras técnicas para medir as magnitudes das quantidades que essas entidades possuem ou para representar as entidades de várias maneiras. Se a história de Laudan tem uma moral antirrealista, é que os postulados pressuposicionais da ciência contemporânea podem náo existir.

Para compreendermos a proposta de Kitcher (1993, p. 101), é preciso abandonar a concepção de que haveria um "modo uniforme de referência para todas as ocorrências de um mesmo tipo". Um termo científico pode ter um "potencial de referência heterogêneo". Aceitando isso, podemos reconhecer, por exemplo, a contribuição oferecida pela teoria do flogisto às suas sucessoras.

Aqui a consideração de sucesso referencial deve estar de acordo com o princípio da caridade ou, mais especificamente, com o que Kitcher (1993, p. 101) chama de princípio da humanidade, segundo o qual devemos atribuir ao interlocutor, que estamos tentando entender, um padrão de relaçóes entre crenças, desejos e o mundo, que seja tão semelhante ao nosso quanto possível.

\section{A NOVIDADE PREDITIVA}

Leplin (1997, p. xii) concebe "a explicação como um veículo para o desenvolvimento do conhecimento". Procura "reestabelecer a ideia do senso comum de que é realizável o conhecimento teórico; de fato, sua realização é parte dos meios para o progresso do conhecimento empírico". Sua estratégia é mostrar que a justificação da passagem do conhecimento empírico para o teórico pode ser dada pelo argumento do milagre, em uma manobra explicacionista. $\mathrm{O}$ argumento do milagre, em sua versão, é fortalecido pela noção de novidade científica.

Leplin (1997) desenvolve seu argumento baseando-se na análise de uma forma de sucesso a que se chega por meio da prática científica - a predição bem-sucedida de resultados empíricos novos. Analisa o impacto que o fenômeno da novidade tem, no contexto da própria ciência, bem como no das teorias metafísicas sobre a ciência, sustentando que podemos inferir do sucesso preditivo novo da teoria uma forma de evidência da verdade (em alguma medida, parcial ou aproximada) de suas proposiçóes. 
De acordo com Leplin (2006, p. 689):

A prática científica atribui peso probatório especial à previsão bemsucedida das teorias de resultados que eram desconhecidos, não explicados, desvalorizados, inesperados, não envolvidos na construção da teoria, sem relação com os testes prévios, improváveis ou contraindicados com base em teorias rivais, imprevisíveis à parte da teoria - uma série de ideias vagamente relacionadas são encapsuladas na concepção científica da novidade.

Para alguns filósofos, a questão da novidade tem sua importância estritamente vinculada ao desenvolvimento do conhecimento empírico. Nesse caso, é de interesse saber quando um resultado empírico traz mais (e novas) crenças sobre o mundo. $\mathrm{O}$ realista, por sua vez, está interessado nas crenças teóricas, mais especificamente, na habilidade de um resultado empírico fornecer garantia epistêmica para a teoria como um todo, incluindo seus postulados teóricos. Por isso, o sentido de novidade de que trata é o epistêmico e não o psicológico.

O fenômeno da novidade preditiva, segundo Leplin (1997), só pode ser explicado por atribuir alguma medida de verdade às teorias que o produziram. Assim, generalizando, o sucesso novo sustenta a teoria e nisso consiste o significado epistêmico da novidade preditiva.

O fim explicativo da ciência emprega a novidade com significado epistêmico especial. Os resultados novos tornam plausível supor que, dentro da prática científica, sua predição bem-sucedida credita às teorias mais do que conformidade geral com a evidência empírica. $\mathrm{O}$ ônus argumentativo fica para aqueles que negam à novidade o seu significado epistêmico. Apenas por interpretar a teoria realisticamente é que se pode explicar a sua façanha do sucesso novo. Interpretaçóes rivais carregam o ônus de explicar por que deve ser tolerada sua deficiência nesse aspecto.

Assevera Leplin (1997, p. 101):

A metodologia que favorece as teorias apenas na medida em que elas se conformam à evidência e não reconhece a relevância epistêmica da novidade é tão deficiente como uma teoria ética que favorece a conduta apenas na medida em que ela se conforma com a justiça e não reconhece a relevância moral do altruísmo. 
Assim, o preceito relevante aqui não é apenas a intuição de que a novidade é importante, mas o fato de que ela desempenha um papel epistêmico na prática avaliativa das teorias, contribuindo para a meta fundamental da ciência: a explicação. Se não podemos explicar o sucesso novo de teorias sem supor que elas contenham verdade, essa meta da ciência requer uma interpretação realista das teorias que prediz exitosamente resultados novos.

Em sua análise, Leplin (1997) distingue duas condições para a novidade: a independência e a unicidade, circunscrevendo, assim, o que lhe é essencial, em um sentido lógico, antes do que psicológico. Para Leplin (2006, p. 690), os "resultados empíricos que satisfazem as condiçóes de independência e de unicidade para a novidade são aqueles cuja previsão bem-sucedida, afirmam os realistas, fornecem garantia para as crenças teóricas". Com essa delimitação do âmbito do sucesso científico novo, que interessa ao realista científico explicar, a aplicação da estratégia explicacionista em defesa do realismo científico alcança uma sofisticação que a torna mais robusta.

A ideia da condição de independência é assegurar que a teoria em questão não tenha sido construída já com o propósito de garantir o seu resultado. Ela deve explicar e prever fenômenos, sem depender desse resultado observacional, no que diz respeito ao seu conteúdo ou desenvolvimento prévio. Procedendo desse modo, não há outra explicação satisfatória para a maneira como a teoria chega a produzir um resultado bem-sucedido do que invocar a existência real das entidades ou processos que ela postula. A explicação do sucesso explicativo e preditivo da teoria deve ser o de que os mecanismos teóricos que ela emprega são aqueles que realmente produzem o resultado. Assim, para explicar o sucesso explicativo e preditivo da teoria, em vez de aceitar um milagre ou sorte, teremos que atribuir alguma medida de verdade a ela.

Nas palavras de Leplin (2006, p. 690):

A novidade requer que um resultado tenha certo tipo de independência da proveniência da teoria que o prevê. Nem o resultado nem qualquer lei ou princípio geral que o subsume pode ter um papel na determinaçáo do que a teoria vai prever. Então, o realista pode argumentar que a previsão bemsucedida do resultado da teoria não fora preordenada, mas exige explicação especial. Essa forma de independência capta a ideia de imprevisibilidade ou distinção, ingredientes na concepção comum de novidade.

Contudo, ainda assim se pode argumentar que o resultado também poderia ser previsto por teorias rivais em relação às quais ele também é inde- 
pendente. Nesse caso, por que deveríamos supor que a explicação realista é necessária? $\mathrm{O}$ realista não deve endossar teorias incompatíveis e lhe falta um princípio basilar capaz de favorecer uma em detrimento de outras. Uma saída para o realista científico poderia ser o estabelecimento de peso ou quantidade de evidência necessário para a seleçáo de uma teoria. Mas, de forma mais simples, como medida adicional, Leplin (1997) propóe a introdução da condição de unicidade para lidar com esse problema.

De acordo com Leplin (2006, p. 690),

a saída mais simples é exigir, como condição da novidade de um resultado, que nenhuma teoria rival viável preveja o mesmo resultado. Entáo, o realista pode argumentar que a única explicação disponível do sucesso preditivo da teoria deve ser encontrada nos méritos epistêmicos próprios da teoria. Esta é uma condição de unicidade. Ela capta a ideia de que não só é um resultado novo, de fato, inesperado, mas é um que os cientistas não tinham motivo para esperar.

A ideia da condição de unicidade é assegurar que a teoria em questáo seja a única com tal habilidade, ou seja, é prevenir que a verdade seja atribuída a uma teoria como explicação de seu sucesso explicativo, quando o mesmo puder ser feito em relaçáo a uma teoria competidora. A menos que elas postulem mecanismos explicativos similares ou não excludentes entre si, apenas uma delas deve ser bem-sucedida, pois tal sucesso é explicado por sua correlação ao real, que é único. Caso contrário, restaria apenas a sorte como explicação.

Leplin (2006, p. 690) acrescenta:

Este requisito é claramente histórico. Ou o status novo é historicamente variável ou deve ser indexado a um estado particular da ciência. Dado os propósitos epistêmicos do realista, é melhor relativizar a novidade para as teorias disponíveis em um determinado momento. Um resultado R é novo no que diz respeito a uma teoria $T$ se satisfaz a condição de independência em relaçáo a $\mathrm{T}$ e, no momento em que $\mathrm{T}$ primeiro o predisse com sucesso, nenhuma rival viável para $T$ também o previu. Entáo, o desenvolvimento posterior de rivais que preveem $\mathrm{R}$ náo afeta a novidade de $\mathrm{R}$ para $\mathrm{T}$, mas o seu peso epistêmico na avaliaçáo de $\mathrm{T}$.

A condição de unicidade, exclusividade, nos remete à questão de restrição temporal: há sempre a possibilidade de surgimento ou reconhecimento de teorias competidoras. Contudo, a novidade (novelty), tal como entendida 
aqui, não é simplesmente uma questão de ser novo (no sentido de new ou temporal newness) ou desconhecido (unknown) para o teórico. Nesse contexto, a diferença entre new e novel é reveladora. $\mathrm{O}$ novo (novel) pode significar o conhecimento adicional, extra, de uma teoria em relação a uma outra.

Conforme esclarece Leplin (2006, p. 689-690), casos paradigmáticos de resultados novos que influenciaram significativamente a avaliação da comunidade científica de uma teoria, como a previsão feita pela relatividade geral da deflexão gravitacional da luz das estrelas, podem sugerir que a novidade importa porque representa a descoberta de um novo fenômeno - que é a, ou uma das, ocupaçóes da ciência. Mas "esse simples desiderato é incompleto". Às vezes, o que se descobre não é o fenômeno, e sim como ele é explicado; um fenômeno conhecido pode continuar sendo considerado novo na medida em que desafia uma explicação teórica. Uma compreensão da novidade é necessária para a distinção entre os propósitos filosóficos de interesse epistêmico de legitimação da crença teórica, do entendimento pragmático do cientista preocupado em aprender sobre o mundo natural.

No caso de Leplin (2006, p. 690), o que se destaca da novidade é sua propriedade de requerer para si própria uma explicação realista: "Um resultado empírico novo deve ser aquele cuja previsão bem-sucedida por uma teoria requer a existência dos postulados inobserváveis da teoria para sua explicaçáo."

Leplin (1997, p. 65) relativiza a novidade ao contexto da própria teoria, mas não ao tempo:

$\mathrm{O}$ que realmente importa para a defesa do realismo não é que a garantia para crenças teóricas seja invulnerável às contingencias históricas, mas que a propriedade de ser garantida seja assim protegida. Não é necessário que uma crença carregue a mesma garantia através de cenários hipotéticos, apenas que continue a ser garantida. (LEPLIN, 1997, p. 127)

A possibilidade de uma afirmação vir a ser frustrada em situações hipotéticas é insuficiente para solapar sua garantia, enquanto ela for garantida em casos concretos.

Notamos que, para os propósitos do realista, segundo Leplin (2006), não é necessário que um resultado empírico novo seja previamente desconhecido, nem mesmo que ele não esteja envolvido na construção da teoria $\mathrm{e}$, inversamente, um resultado totalmente desconhecido, novo em todos os aspectos, também não garante a novidade lepliniana. Isso porque, no primeiro 
caso, pode ocorrer que, embora o teórico tenha usado tal resultado empírico, não precisava ter agido assim; seu uso pode ter sido meramente incidental, visto que sua omissão não teria afetado o desenvolvimento da teoria. No segundo caso, o resultado, mesmo desconhecido, pode instanciar um princípio geral assumido no desenvolvimento da teoria ou ser intercambiável no desenvolvimento da teoria com resultados conhecidos cruciais para determinar as capacidades preditivas da teoria. "Nesses casos, a proveniência [provenance] da teoria é tal que ela naturalmente prediria o resultado se suas postulaçóes garantissem uma interpretação realista ou não.” (p. 690).

Uma teoria não precisa ser aproximadamente verdadeira para ser bem-sucedida, mas as teorias bem-sucedidas que fazem, necessariamente, uso de determinadas entidades inobserváveis em suas explicaçóes e previsóes nos dão razão para acreditar em sua verdade, em alguma medida.

Leplin (1997, p. 104) enfatiza:

Interpretar uma teoria realisticamente consiste em supor que apenas os seus mecanismos explicativos capturam algum dos aspectos do processo natural, suficientemente bem, a ponto de não se enganar sobre como são realmente produzidos os efeitos que esses mecanismos explicam. Uma interpretação realista afirma que a teoria revela alguma verdade significativa sobre os processos reais, em que a "significância" é a relevância para nossos fins explicativos, e "alguma" é uma medida proporcional a esses fins. A verdade da qual o realismo se ocupa não é o tudo ou nada, a verdade bivalente que se atém definitivamente às proposiçóes discretas uma por uma.

A interpretação realista de uma teoria considera os seus mecanismos explicativos como sendo representativos de processos reais da natureza, ou seja, daqueles processos que produzem os efeitos que nos são acessíveis observacionalmente na experiência ou experimento de teste. Nesse sentido, uma interpretaçáo realista atribui alguma medida de verdade para a teoria, uma vez que a verdade é entendida como acuidade da representação.

Acrescenta Leplin (2006, p. 687):

Caracteristicamente, o realismo fala da existência de "alguma verdade" da teoria, mas se recusa a ser totalmente explícito quanto ao que é esta verdade. O realismo afirma haver verdade suficiente para dar conta [to account] da eficácia preditiva e explicativa dos postulados inobserváveis. Mas não sabendo quanto ou que tipo de verdade é suficiente, o realismo não pode converter suas atribuiçôes de verdade em afirmaçôes teóricas específicas. 
A afirmação de que as teorias empiricamente bem-sucedidas devem ser pelo menos parcialmente verdadeiras é desenvolvida como a única alternativa para o mistério. Não há um modo de entender como a ciência pode ser bem-sucedida, se os mecanismos explicativos que ela postula não forem representativos dos processos reais da natureza. Essa afirmaçáo pode soar forte demais. De fato, há casos nos quais sucessos científicos são explicados sem imputar verdade às teorias que os realizam. A estratégia antirrealista é justamente provocar uma proliferaçáo de explicaçóes para o sucesso. Mas em nenhum desses casos, em que se admite outra explicação, têm-se o tipo especial de sucesso, o sucesso novo, tal como analisado por Leplin (1997). A explicação de uma previsão bem-sucedida para um resultado empírico novo requer a existência dos postulados inobserváveis da teoria. A partir dessa análise, o realismo é favorecido em relação aos seus rivais antirrealistas.

\section{A feCundidade teórica}

Muitas defesas são feitas ao realismo científico, todavia, o diferencial do argumento de McMullin (1984, p. 26) consiste em sua "ênfase nos tipos estruturais de explicação e no papel desempenhado pelo critério da fecundidade em tais explicações".

Segundo McMullin (1984), quando Galileu argumentou que os padrôes familiares de luz e sombra na face da Lua cheia poderiam ser melhor explicados ao supor que a Lua possui montanhas e mares como aqueles da Terra, ele estava empregando um modo de inferência e explicação que não era novo para a ciência natural, mas que, desde então, ficou reconhecido como central para a explicaçáo científica. O que Galileu fez foi propor um modelo cujas propriedades permitiam explicar o fenômeno em questão.

Avaliar e escolher modelos é uma tarefa complexa, que depende da seleção de critérios fundamentados, como os de coerência, fecundidade, adequação aos dados disponíveis. Os construtos teóricos empregados no modelo variam desde um tipo já familiar, como "montanha" e "mar", no modelo da Lua de Galileu, até aqueles criados pelos cientistas especificamente para o caso em questão, como "neutrinos".

Para o realista científico, o sucesso do modelo permite, ao cientista, inferir a existência das entidades postuladas no modelo, sejam elas de tipo familiar ou não. Como observa McMullin (1984, p. 8): "O imenso e contínuo 
sucesso das retroduçôes que empregam esses construtos é (aos olhos dos cientistas) um testemunho suficiente para isso." Evidentemente, isso não descarta a falibilidade da ciência. Os próprios cientistas frequentemente duvidam da existência de alguns de seus construtos teóricos e, muitas vezes, estão certos em fazê-lo. Entretanto, a sua dúvida, comumente, não se deve a um "sentimento antirrealista geral", mas à intuição proveniente de alguns aspectos especiais dos próprios construtos particulares, que podem sugerir que eles sejam "bagagem extra - interpretaçóes adicionais impostas sobre as próprias teorias - como as esferas cristalinas pareceram, para muitos astrônomos entre Ptolomeu e Copérnico" (p. 10). Esses casos particulares não abalam a crença geral de que descobrimos mais e mais sobre as entidades das quais o mundo é composto.

A pergunta filosófica é: quão confiável é essa crença? O realismo científico é a doutrina filosófica que procura restabelecer a confiabilidade dessa crença, a partir da formulação de argumentos apropriados. $\mathrm{O}$ argumento do milagre é um deles.

Reiterando seu compromisso com o realismo científico, a partir da abordagem da convergência da explicação estrutural, McMullin (1984, p. 26) esclarece que a afirmação básica feita pelo realista científico é que:

O sucesso de longo prazo de uma teoria científica fornece razão para se acreditar que algo como as entidades e estruturas postuladas pela teoria realmente existem. Há quatro qualificaçóes importantes levantadas nisso: (1) a teoria deve ser bem-sucedida em um período de tempo significativo; (2) o sucesso explicativo da teoria oferece alguma razão para se acreditar nela, embora não uma garantia conclusiva; (3) no que se acredita é que as estruturas teóricas são algo parecido [something like] com a estrutura do mundo real; (4) nenhuma afirmação é feita de que as entidades postuladas têm uma forma de existência especial, mais básica, privilegiada.

De acordo com McMullin (1984), dos cinco valores listados por Kuhn (1977), como aqueles considerados pelos cientistas ao avaliarem uma teoria científica - acuidade preditiva, consistência, amplitude de escopo, simplicidade e fertilidade -, o último é o que mais diretamente está relacionado à problemática do realismo. "A fertilidade é geralmente equiparada à capacidade de fazer previsões novas." (McMULLIN, 1984, p. 30). Com efeito, a geração de novidade seria o primeiro aspecto da fertilidade. Espera-se de uma boa teoria que ela seja capaz de prever fenômenos novos, ou seja, aqueles que não fazem parte do conjunto original a ser explicado desde o início; e, quanto mais 
inesperados forem esses fenômenos novos, melhor será considerado o modelo. "A exibição deste tipo de fertilidade reduz a probabilidade de a teoria ser ad hoc." (McMULLIN, 1984, p. 30). Embora, na visão do antirrealista, tal noção seja arbitrária, para o realista, ela desempenha um papel importantíssimo. Isso porque, conforme o realista, uma hipótese ad hoc não é genuína, ou seja, não oferece qualquer insight sobre a estrutura real e, consequentemente, não apresenta qualquer fundamento para a expansão da teoria. Para o antirrealista, a previsão de fatos novos pela teoria simplesmente aumenta o seu escopo e, assim, a faz mais aceitável. "Quando a teoria é proposta, inicialmente, muitas vezes é difícil dizer se é ou não é ad hoc com base em outros critérios de avaliação da teoria. É por isso que a fertilidade é um critério tão importante do ponto de vista realista." (McMULLIN, 1984, p. 30-31).

O segundo aspecto da fertilidade, o seu poder metafórico, é, de acordo com McMullin (1984, p. 31),

notado com menor frequência, mas pode ser mais significativo para o nosso problema. $\mathrm{O}$ primeiro aspecto da fertilidade, a novidade, tinha a ver com o que logicamente pode ser inferido a partir da teoria, seus recursos lógicos, pode-se dizer. Mas um bom modelo tem mais recursos do que esses. Se uma anomalia for encontrada ou se a teoria for incapaz de prever de um modo ou de outro em um domínio em que parece que deveria ser capaz de fazer isso, o próprio modelo pode servir para sugerir modificaçóes possíveis ou extensóes. Essas são sugeridas, não implicadas. Portanto, um movimento criativo da parte do cientista é necessário.

Nesse caso, o modelo funciona um pouco como uma metáfora na linguagem. $\mathrm{O}$ poeta usa uma metáfora não exatamente como ornamento, mas como um meio de expressar um pensamento complexo. Uma boa metáfora tem seu próprio tipo de precisão [...]. Ela pode conduzir a mente a caminhos que a linguagem literal não pode. $\mathrm{O}$ poeta que está desenvolvendo uma metáfora é conduzido por sugestão, não por implicação; o leitor do poema consulta a metáfora e pesquisa entre suas várias ressonâncias aquela que parece melhor comportar o insight.

Se considerarmos no decurso da história da ciência os casos de teorias férteis, poderemos identificar o segundo aspecto da fertilidade e sua relevância para o desenvolvimento do conhecimento. McMullin (1984, p. 32) apresenta um modelo da geologia que tem algo desse "poder metafórico":

Havia ficado conhecido que a costa oeste da África e a costa leste da América do Sul mostram semelhanças marcantes, em termos de estratos e seu conteúdo fóssil. Em 1915, Alfred Wegener apresentou uma hipótese 
para explicar essas e outras similaridades, tais como aquelas entre os principais sistemas de dobras na Europa e América do Norte. A noção de deriva continental que ele desenvolveu em $A$ origem dos Continentes e dos Oceanos não era no início aceita, embora admitidamente as explicasse em grande medida. Havia também muitas anomalias: Como os continentes poderiam ser talhados até o fundo do oceano, por exemplo, uma vez que o material do fundo do oceano é consideravelmente mais rígido do que o dos continentes? Nos anos de 1960, novas evidências de que o fundo do mar se deslocava levaram $\mathrm{H}$. Hess e outros à modificação do modelo original. Os elementos se movendo não são os continentes, mas sim grandes placas em que os continentes bem como o fundo do mar são carregados. E assim a hipótese da deriva continental desenvolveu-se no modelo das placas tectônicas.

Este é um caso típico em que o recurso à metáfora foi indispensável. A criatividade dos cientistas desempenhou o papel de reunir os diversos insights disponíveis para propor a alternativa adequada ao desenvolvimento do conhecimento. Segundo McMullin (1984, p. 32):

A entidade teórica original, um continente flutuante, não implicava logicamente as placas do novo modelo. Mas, no contexto das anomalias e de nova evidência, ela o sugeriu. E essas placas, por sua vez, sugeriram novas modificaçôes. Quando as placas se afastam, acontecem fissuras no fundo do mar, com propriedades muito específicas. A lava ressurgindo terá propriedades direcionais magnéticas que dependerá de sua orientação em relaçáo ao campo magnético da Terra no momento. Isso permite que a lava seja datada e que a separaçáo gradual das placas seja mapeada. Foi a descoberta de tais camadas [strips] datadas, paralelas às fendas oceânicas, que se revelou decisiva no balanço dos geólogos sobre o novo modelo em meados dos anos de 1960. O que acontece quando as placas colidem? Uma é levada para baixo (subducção), a outra pode ser empurrada para cima para formar um cume da montanha. Pode-se ver aqui como a metáfora inicial é gradualmente estendida e tornada mais específica.

A crítica mais imediata à proposta de McMullin (1984) é o caráter vago da noção de metáfora (segundo aspecto da fertilidade) por ele empregado como forma de fortalecimento do argumento de defesa do realismo científico, o argumento do milagre.

Como resposta àqueles que exigem uma "abordagem suficientemente precisa de metáfora”, McMullin (1984, p. 32), a partir do exemplo acima reproduzido, simplesmente enfatiza o que entende por metáfora: "Se o modelo 
original (digamos, a deriva continental) sugeriu, mais tarde, a modificação como um modo plausível de atender às anomalias conhecidas e de incorporar as novas evidências, então, eu chamo isso de uma extensão metafórica."

É possível questionar, ainda, utilizando o mesmo exemplo, se o modelo da deriva continental e o das placas tectônicas são dois estágios de desenvolvimento da mesma teoria ou duas teorias completamente diferentes. Como já foi dito anteriormente, para McMullin (1984), há continuidades estruturais de um estágio ao próximo, embora também haja importantes modificaçóes estruturais. $\mathrm{O}$ mais importante a se notar aqui é que o que permite que se identifique essa continuidade "é a metáfora subjacente da mobilidade dos continentes que estiveram em contato há muito tempo" (p. 33). Para o realista, a suposição que melhor explica é a de que o modelo se aproxima suficientemente bem das estruturas do mundo, as quais são causalmente responsáveis pelos fenômenos a serem explicados. É exatamente por isso que é vantajoso para o cientista levar em conta seriamente as extensôes metafóricas do modelo.

$\mathrm{O}$ argumento de McMullin (1984, p. 33-34), em sua abordagem explicativo-estrutural apoiada por sua noção de fertilidade, prossegue:

\begin{abstract}
Alguns aspectos teóricos do modelo, tal como as fendas oceânicas, poderiam ser testados diretamente e sua existência observacionalmente mostrada. [...] entidades teóricas ${ }^{5}$ previamente não observadas, ou em alguns casos mesmo consideradas inobserváveis, são de fato observadas e as expectativas da teoria se confirmam, para a surpresa de ninguém. A separação entre observável e inobservável postulada por muitos antirrealistas em relaçáo ao status ontológico náo parece levantar-se. $\mathrm{O}$ mesmo modo de argumento é usado em cada caso; não é claro por que em um caso as expectativas de existência real são concedidas às entidades teóricas, enquanto em outros casos, similares logicamente no caráter explicativo, essas expectativas são negadas. A inferência ontológica [...] deve ser muito mais hesitante em alguns casos do que em outros. Náo há dúvida em conceder o mesmo status ontológico a todas as entidades teóricas em virtude de um grau semelhante de fertilidade evidenciado ao longo de um período de tempo significativo. No entanto, tal fertilidade encontra sua melhor explicação em uma abordagem amplamente realista da ciência.
\end{abstract}

\footnotetext{
${ }^{5}$ McMullin fala de 'entidades teóricas'. Contudo, como observa van Fraassen (1980), isso constitui um erro categorial: entidades são observáveis ou inobserváveis; os termos é que são teóricos. Para fim de clareza, cabe dizer que por entidades teóricas aqui se entendem aquelas entidades postuladas pelas teorias científicas que são inobserváveis (também, por vezes, chamadas de "termos teóricos"), e que se opóem às chamadas entidades observacionais ou termos observacionais, os quais se referem a entidades observáveis (ou "não-teóricas"). Em What theories are not, Hilary Putnam [(1962) 1975] faz uma crítica incisiva à dicotomia observacional/teórico aplicada a termos ou enunciados.
} 
$\mathrm{Na}$ interpretação de McMullin (1984), o realista científico não defende que a aceitação de uma teoria implique a crença de que ela é verdadeira. Sabe-se que os cientistas se sentiriam inconfortáveis com o uso do termo 'verdadeiro', pois ele sugere que a teoria seja definitiva em sua formulação, e esse não é o caso para se reivindicar. Para o realista científico, a ciência tem por objetivo alcançar uma metáfora fecunda e uma estrutura que seja cada vez mais detalhada. Para isso, a suposição de que uma teoria seja literalmente verdadeira só atrapalharia, pois acarretaria, por exemplo, a impossibilidade do surgimento de anomalias, que é importante para o desenvolvimento progressivo das teorias.

Segundo McMullin (1984, p. 35), “os recursos à metáfora são essenciais ao trabalho da ciência e a construção e a retenção de metáfora devem ser vistas como parte do objetivo da ciência". Já a noção de "aceitação" é pragmática: pode-se aceitar uma explicação por ser a melhor disponível; pode-se aceitar uma teoria como uma boa base para pesquisas futuras, e assim por diante.

Destaca McMullin (1984, p. 35):

Em nenhum caso seria correto dizer que a aceitação de uma teoria implica a crença em sua verdade.

O realista não usaria o termo 'verdadeiro' para descrever uma boa teoria. Ele suporia que as estruturas da teoria oferecem algum insight sobre as estruturas do mundo. Mas ele não poderia, em geral, dizer quão bom é o insight. Ele não tem acesso independente ao mundo, como o antirrealista constantemente o relembra. Sua garantia de que há um ajuste, porém grosseiro, entre as estruturas da teoria e as estruturas do mundo não vem de uma comparaçáo entre elas, mas a partir do tipo de argumento que esbocei acima, que conclui que apenas esse tipo de raciocínio explicaria certos aspectos contingentes da história da ciência recente.

É nesse sentido que o realista científico prefere falar de "verdade parcial" ou "aproximada". No entanto, essa terminologia, utilizada pelo realista científico, também pode muitas vezes incitar possíveis questionamentos céticos: como e quanto uma teoria pode estar próxima da verdade? Para o realista científico, segundo McMullin (1984), tais questôes não têm uma resposta, simplesmente, porque são inapropriadas. A linguagem da explicação teórica é de um tipo muito especial: ela é metafórica. 


\section{CONSIDERAÇÓES FINAIS}

Não obstante os erros e as falhas da ciência, o seu sucesso empírico (instrumental) é reconhecido. Desse modo, faz-se necessária ou, pelo menos, se mostra relevante a explicaçáo desse sucesso. Para o realista científico, a ciência é bem-sucedida em explicar e prever fenômenos, inclusive novos, porque suas melhores teorias (maduras, não ad hoc, bem-sucedidas empírica e instrumentalmente, provedoras de previsóes novas, fecundas etc.) são verdadeiras, parcial ou aproximadamente verdadeiras, e seus métodos, baseados nas teorias aceitas, são confiáveis na busca da verdade. Descartando a explicaçáo realista para o sucesso da ciência, restaria o "milagre" ou uma "coincidência cósmica" como formas de explicação. Não deveríamos aceitar milagres ou acaso como explicação, não, pelo menos, se há uma alternativa disponível. O realismo científico, portanto, constitui a melhor, senão a única, explicação razoável para o sucesso da ciência. Ao responder às críticas que são dirigidas ao argumento do milagre, o realismo científico é aperfeiçoado. No sentido de fortalecer o argumento do milagre, levamos em consideração dois aspectos fundamentais na argumentação em defesa do realismo científico: a novidade preditiva e a fecundidade teórica.

Ainda que o realismo científico tenha alcançado uma sofisticação que lhe permita responder adequadamente às críticas que lhe são dirigidas, obviamente, a posição realista científica não está livre de concorrentes. No entanto, como argumentamos em outra ocasiáo (SOUZA, 2015), as alternativas apresentadas (historicismo, anarquismo, empirismo construtivo e a abordagem metodológica) não alcançam o mesmo êxito que o realismo científico em explicar o sucesso da ciência. A nosso ver, o realismo científico se apresenta como a concepção mais razoável sobre o estatuto cognitivo das teorias científicas. ${ }^{6}$

SOUZA, E. A. On the philosophical relevance of the miracle argument. Trans/formlação, Marília, v. 42, n. 4, p. 47-80, Out./Dez., 2019.

\footnotetext{
${ }^{6}$ Agradecimentos: Este artigo resulta de minha pesquisa de Doutorado, realizada na Faculdade de Filosofia, Letras e Ciências Humanas da Universidade de São Paulo (FFLCH/USP), com o apoio financeiro do CNPq. Agradeço a essas instituiçóes pelas condiçóes de trabalho que me foram oferecidas. Sinto-me agradecida a todas e a todos com as/os quais discuti sobre o tema deste artigo. Em especial, agradeço ao Professor Dr. Caetano Ernesto Plastino, da FFLCH - USP, por sua orientação dedicada e pelo incentivo e leitura cuidadosa deste artigo, cujos equívocos, acaso persistam, são exclusivamente de minha responsabilidade.
} 
ABSTRACT: In this article, we argue in favor of a sophisticated version of scientific realism, based on an analysis of what we consider to be the strategic element of its defense: the "miracle argument". Scientific realism is the perspective applicable to our best scientific theories; that is, it applies to entities, processes, and relationships, etc., whether observable or unobservable, which are indispensable for explaining the empirical success of theories, and it applies particularly to those components of the theories that are crucial to achieving new and successful forecasts. The miracle argument is a type of abduction or inference to the best explanation, and is expressed in the famous formulation of Putnam (1975, p. 73): "[Scientific] realism is the only philosophy that doesn't make the success of the science a miracle." We analyze and refute two important modes of antirealist argument: pessimistic induction and vicious circularity of inference to the best explanation. We believe that we are justified in defending the basic intuition of scientific realism, supported by a strengthened version of the miracle argument, together with the attributes of predictive novelty and theoretical fecundity. From this perspective, science succeeds in explaining and predicting phenomena, including new phenomena, because its best theories (mature, non-ad hoc, empirically and instrumentally successful, providing new and fertile predictions, etc.) are (partially or approximately) true, and the unobservable entities postulated by these theories actually exist. We conclude that the miracle argument continues to be basic and strategic in the defense of scientific realism.

KeYwords: Scientific realism. Miracle argument. Anti-realism. Predictive novelty. Theoretical fecundity.

\section{REFERÊNCIAS}

BOYD, R. N. [1983] The current status of scientific realism. In: LEPLIN, J. (ed.) Scientific realism. Berkeley, Los Angeles, London: University of California Press, 1984. p. 195-222.

BOYD, R. N. Scientific realism. In: Stanford Encyclopedia of Philosophy. 2002. Disponível em: http://plato.stanford.edu/entries/scientific-realism/ Acesso em: 10 set. 2019.

BUNGE, M. Treatise on basic philosophy. V. 1. Semantics I: sense and reference. BostonUSA: D. Reidel, 1974.

FEYERABEND, P. Against method. London: NLB, 1975.

FINE, A. The natural ontological attitude. In: LEPLIN, J. (ed.) Scientific realism. Berkeley, Los Angeles, London: University of California Press, 1984. p. 261-277.

KITCHER, F. The advancement of science: science without legend, objectivity without illusions. Oxford: Oxford University Press, 1993.

KUHN, T. Objectivity, value judgement and theory Choice. In: KUHN, T. The essential tension. Chicago: University of Chicago Press, 1977. p. 320-39.

LAUDAN, L. [1981] A Confutation of convergent realism. In: LEPLIN, J. (ed.) Scientific realism. Berkeley, Los Angeles, London: University of California Press, 1984. p. 41-82.

LEPLIN, J. Introduction. In: LEPLIN, J. (ed.) Scientific realism. Berkeley, Los Angeles, London: University of California Press, 1984. 
LEPLIN, J. A novel defense of scientific realism. New York, Oxford: Oxford University Press, 1997.

LEPLIN, J. Realism. In: SARKAR, S.; PFEIFER, J. The philosophy of science: an encyclopedia. New York: Routledge, 2006. V. 1.

McMULLIN, E. A case for scientific realism. In: LEPLIN, J. (ed.) Scientific realism. Berkeley, Los Angeles, London: University of California Press, 1984. p. 8-40.

PSILLOS, S. Scientific realism: how science tracks truth. London, New York: Routledge, 1999.

PUTNAM, H. Introduction: science as approximation to truth. What is mathematical truth? In: PUTNAM, H. Mathematics, matter, and method. Cambridge: Cambridge University Press, 1975. (Philosophical Papers, v. 1).

PUTNAM, H. [1962] What theories are not. In: PUTNAM, H. Mathematics, matter, and method. Cambridge: Cambridge University Press, 1975. (Philosophical Papers, v. 1).

PUTNAM, H. [1976] Lecture II. In: PUTNAM, H. Meaning and the moral sciences. Boston, London, Henley: Routledge \& Kegan Paul, 1978.

PUTNAM, H. [1990] Renewing philosophy. Cambridge: Harvard University Press,1992.

PUTNAM, H. The threefold cord: mind, body, and world. New York: Columbia University Press, 1999.

PUTNAM, H. [2010] On not writing off scientific realism. In: PUTNAM, H. Philosophy in an age of science: physics, mathematics, and skepticism. Cambridge: Harvard University Press, 2012.

SOUZA, E. A. Os realismos de Putnam e seu argumento do milagre. In: CARVALHO, M.; FIGUEIREDO, V. (org.). Filosofia contemporânea: lógica, linguagem e ciência. São Paulo: ANPOF, 2013. p. 227-244.

SOUZA, E. A. Um estudo do argumento do milagre na defesa do realismo cientifico. 2015. Tese (Doutorado) - Faculdade de Filosofia, Letras e Ciências Humanas, Universidade de São Paulo, São Paulo, 2015.

VAN FRAASSEN, B. C. The scientific image. Oxford: Clarendon, 1980.

Recebido: 24/11/2017

Aceito: 14/03/2018 